\title{
CEJ Smoothing
}

A. Two isolated element edges
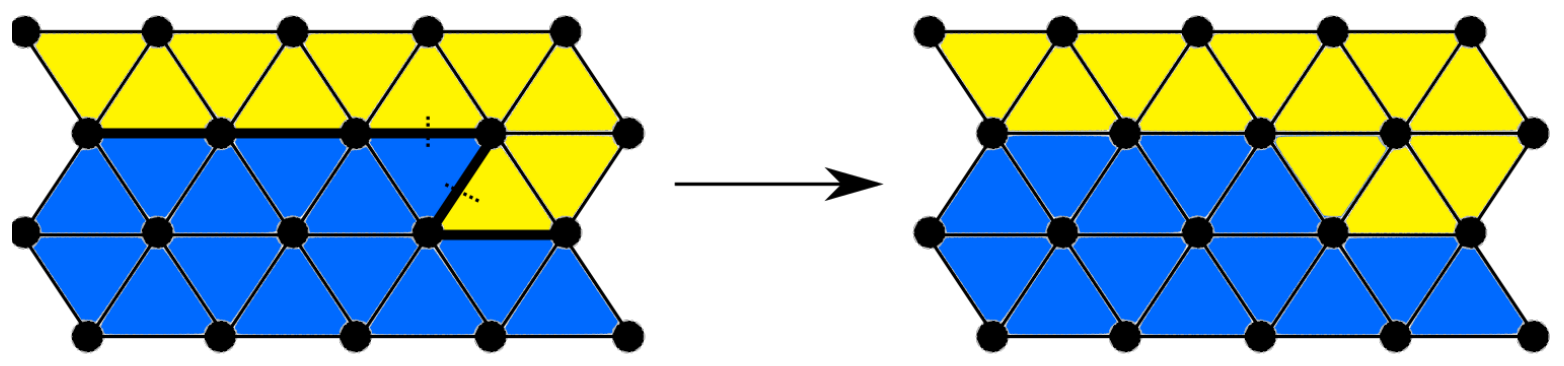

B. 3 Isolated element edges
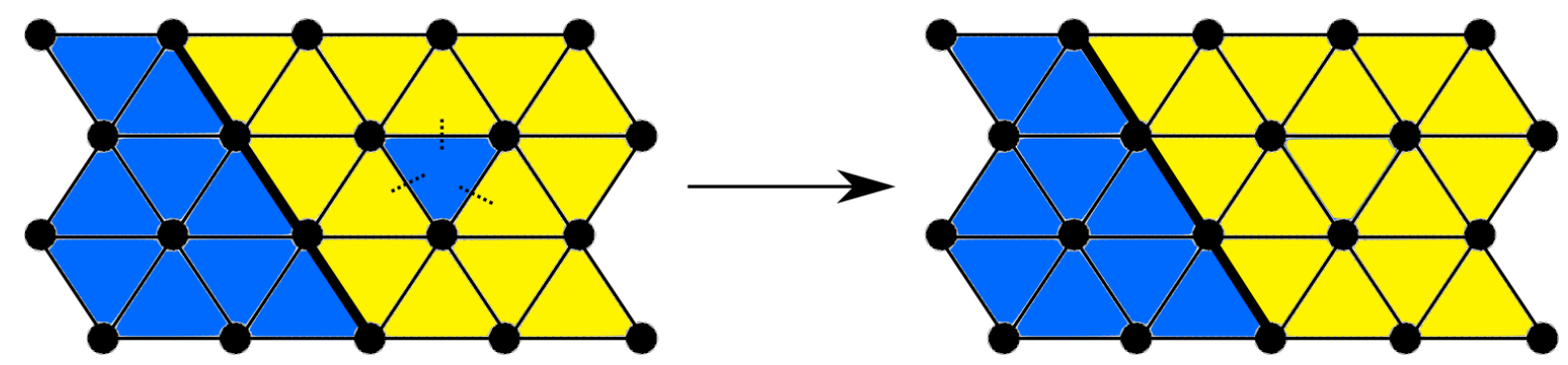